\title{
The Gulf of Nicoya estuary, Costa Rica: Past, present, and future cooperative research
}

\author{
J. A. Vargas \\ Universidad de Costa Rica, Centro de Investigación en Ciéncias del Mar y Limnología \\ (CIMAR); 2060 San Pedro, Costa Rica, Central America
}

\begin{abstract}
The Gulf of Nicoya is a tectonic estuary on the Pacific coast of Costa Rica $\left(10^{\circ} \mathrm{N}-85^{\circ} \mathrm{W}\right)$, extending about $100 \mathrm{~km}$ from the Tempisque river to the $500 \mathrm{~m}$ isobath. A dry season (DecemberApril) and a rainy season (May-November) exert a significant impact on its water characteristics. The estuary is the most important fishing ground of Costa Rica, and the main Pacific ports are located within it. Coastal zone development has increased in recent years. In 1979 a research programme to study the Gulf was established at the University of Costa Rica, and foreign scientists were invited to work jointly with local experts to achieve the goals of the evaluation. More than 80 papers have been published to date, making the Gulf one of the best known tropical estuaries. The study of soft-bottom communities is an important component of this research programme. Past benthic research focused on the description of the structure of communities, while future efforts will find an unexplored field in the study of energy flow and community interactions. More than 200 species of fish, and 400 of benthic invertebrates have been identified. Future cooperative research is most welcome in larval ecology, interactions between size groups, and physiological tolerances. Considerable experience has been accumulated in the experimental manipulation of soft-bottom communities of high latitudes. This branch of ecology, however, remains little explored in the tropics. Future cooperative efforts in the Gulf of Nicoya will be established on solid ground, formed by a data base that has been improved since 1979, the existence of a marine research centre and a group of active, local scientists who have experience in working together with foreign expertise.
\end{abstract}

\section{INTRODUCTION}

Ecological data on tropical estuaries are scarce and fragmentary. This information is essential for the conservation and management of shallow tropical marine ecosystems (Hatcher et al., 1989). One exception, however, is the literature available on the Gulf of Nicoya, an estuary located at $10^{\circ} \mathrm{N}-85^{\circ} \mathrm{W}$ on the Pacific coast of Costa Rica, Central America (Fig. 1). The Gulf is the main fishing ground (finfish, penaeid shrimp, shellfish) of the country. In addition, coastal zone development (ports, housing complexes, tourism) has increased drastically over the past ten years. The conflicting nature of these exploits, together with the lack of ecological information to aid in policy making, prompted the University of Costa Rica to create, in 1979, the Centre for Research in Marine Science and Limnology (CIMAR). A research programme to conduct a long-term multidisciplinary evaluation of the Gulf was also established in the same year, and foreign scientists were invited to work jointly with local experts to achieve the goals of the evaluation. More than 80 papers have been published to date, making the Gulf one of the better known tropical estuaries worldwide. Cooperative research with foreign research laboratories played, 


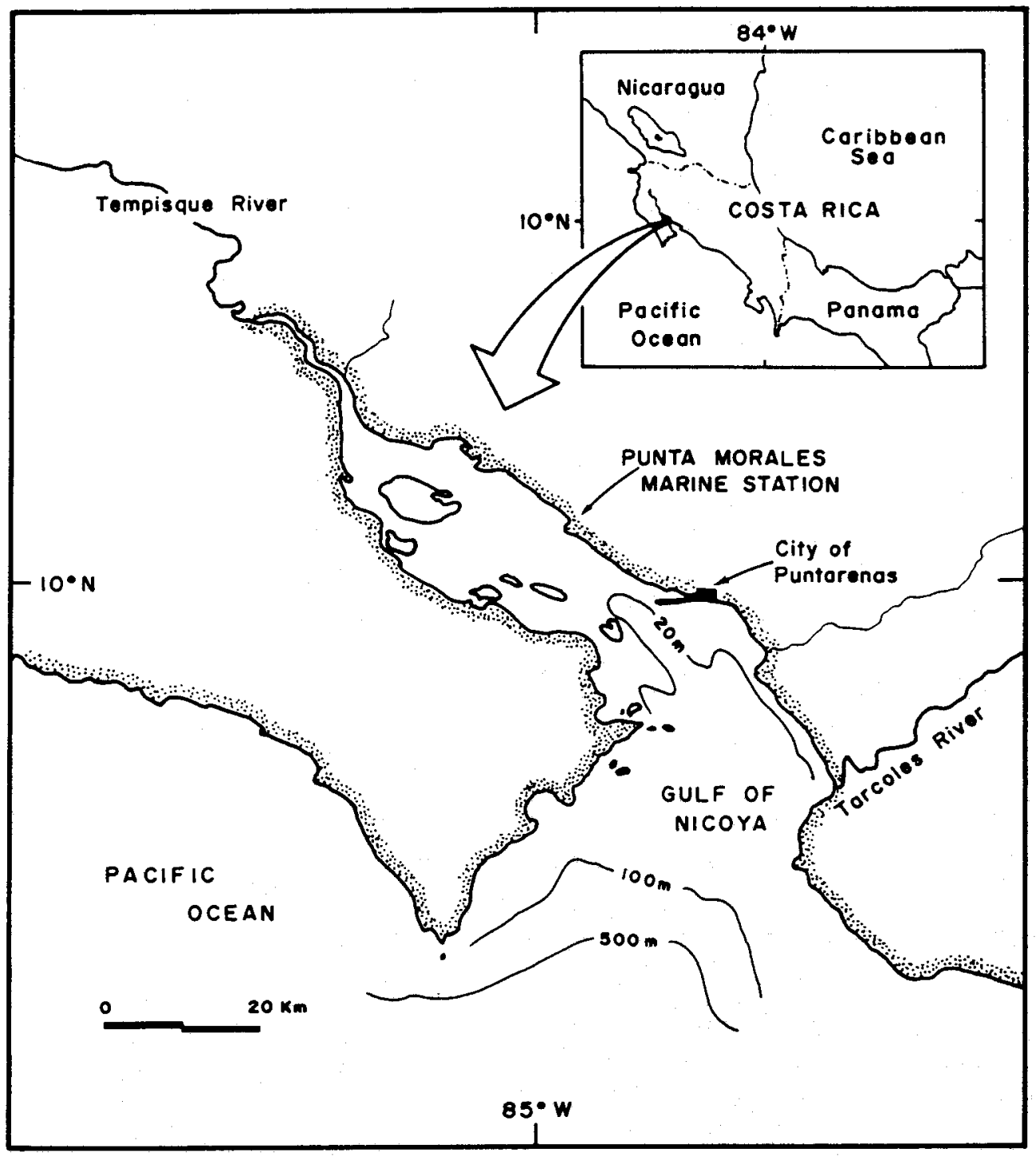

Fig. 1. Gulf of Nicoya estuary, Pacific coast of Costa Rica, Central America. Note close proximity of deep waters of the Pacific Ocean to the shallow waters of the Gulf

and continues to play, a key role in the development of the data base. On the occasion of the Centenary of the Biologische Anstalt Helgoland, the title of the Symposium "The Challenge to Marine Biology in a Changing World" bears special significance for the tropical marine biologist, as mankind is making serious efforts to preserve and manage tropical marine biodiversity. These efforts require increased cooperation between scientists from temperate and tropical institutions. The nature of this cooperation will take shape faster if past research efforts are known and research priorities identified. Thus, the 
objective of this paper is to present an overview of the results of research conducted in the Gulf of Nicoya over the past decade.

\section{RESEARCH OVER THE PAST DECADE}

During the first years of the research programme supporting the ecological evaluation of the Gulf of Nicoya, a key role was played by a joint effort between CIMAR and the University of Delaware's College of Marine Studies (CMS). This effort included the transfer to CIMAR of a CMS research vessel, the training of the local crew and technical personnel, and the exchange of faculty and students. The joint project was concluded in 1982; however, cooperation between individual scientists continues, to date (Tables 1 and 2). An important factor leading to the success of the venture was the participation of scientists and students from both institutions in all stages of project development, from

Table 1. Main topics of research in the ecological evaluation programme of the Gulf of Nicoya and selected publications, including those resulting from past cooperation between the University of Costa Rica (CIMAR) with similar institutions

\begin{tabular}{|c|c|c|}
\hline Topics & Selected references & Institutions \\
\hline Estuarine flow & $\begin{array}{l}\text { Voorhis et al. (1983) } \\
\text { Murillo (1990) }\end{array}$ & $\begin{array}{l}1,2,3,4 \\
1\end{array}$ \\
\hline $\begin{array}{l}\text { Nutrients, dissolved oxygen, } \\
\text { trace metals }\end{array}$ & $\begin{array}{l}\text { Epifanio et al. (1983) } \\
\text { Dean et al. (1986) } \\
\text { Fuller et al. (1990) }\end{array}$ & $\begin{array}{l}1,2,3 \\
1,3,3,5 \\
1,6\end{array}$ \\
\hline $\begin{array}{l}\text { Fish diversity and distribution, } \\
\text { mass mortality, artificial reefs, } \\
\text { ichthyoplankton }\end{array}$ & $\begin{array}{l}\text { Bartels et al. (1983, 1984) } \\
\text { Campos et al. (1984) } \\
\text { Thorne et al. (1989) } \\
\text { Szelistowski \& Garita (1989) } \\
\text { Campos \& Gamboa (1989) } \\
\text { Ramirez et al. (1989, 1990) }\end{array}$ & $\begin{array}{l}1,2 \\
1 \\
1,7 \\
1,10,8 \\
1 \\
1\end{array}$ \\
\hline $\begin{array}{l}\text { Crab larvae, lunar rhythms, dispersal, } \\
\text { hermit and blue crabs, seasonality }\end{array}$ & $\begin{array}{l}\text { Epifanio \& Dittel (1982) } \\
\text { DeVries et al. (1983a, b) } \\
\text { Dittel \& Epifanio }(1984) \\
\text { Epifanio \& Dittel }(1982,1984) \\
\text { Dittel et al. (1985, 1991) } \\
\text { Borjesson \& Szelistowski (1989) } \\
\text { Wehrtmann (1990) } \\
\text { Wehrtmann \& Dittel (1990) }\end{array}$ & $\begin{array}{l}1,2 \\
1,2 \\
1,2 \\
1,2 \\
1,2 \\
1 \\
1,9 \\
1,9\end{array}$ \\
\hline Mangroves, marine fungi, red tides & $\begin{array}{l}\text { Soto }(1988) \\
\text { Perry }(1988) \\
\text { Gocke et al. (1990) } \\
\text { Ulken et al. }(1990)\end{array}$ & $\begin{array}{l}1 \\
1,10 \\
1,11 \\
1,8,12\end{array}$ \\
\hline \multicolumn{3}{|c|}{$\begin{array}{l}\text { 1: Universidad de Costa Rica (CIMAR); 2: University of Delaware, Lewes (USA); 3: California } \\
\text { State University, Long Beach (USA); 4: Woods Hole Oceanographic Institution, Woods Hole } \\
\text { (USA); 5: Mount Ida College, Boston (USA); 6: United States Geological Survey (USA) } \\
\text { 7. University of Washington (USA); 8: Universidad Nacional, Heredia (Costa Rica); 9: Universität } \\
\text { Hamburg (Germany); 10: University of California, Los Angeles (USA); 11: Institut für Meeres } \\
\text { kunde, Kiel (Germany); 12: Alfred Wegener Institut, Bremerhaven (Germany) }\end{array}$} \\
\hline
\end{tabular}


Table 2. Main topics of soft-bottom research in the ecological evaluation programme of the Gulf of Nicoya and selected publications, including those resulting from past cooperation between the University of Costa Rica (CIMAR) with similar institutions

\begin{tabular}{|c|c|c|}
\hline Topics & Selected references & Institutions \\
\hline $\begin{array}{l}\text { Subtidal be nth os } \\
\text { faunal surveys, diversity, latitudinal } \\
\text { comparisons, polychate seasonal abundance, } \\
\text { feeding guilds, stomatopods }\end{array}$ & $\begin{array}{l}\text { Maurer et al. (1984) } \\
\text { Maurer \& Vargas (1984) } \\
\text { Vargas et al. (1985) } \\
\text { Maurer et al. (1988) } \\
\text { Dittel (1991) }\end{array}$ & $\begin{array}{l}1,2,3 \\
1,3 \\
1,3,5 \\
1,3,5 \\
1\end{array}$ \\
\hline $\begin{array}{l}\text { In tertid a l be n thos } \\
\text { oxygen consumption, meiofauna, macro- } \\
\text { fauna, seasonal abundance, predation, } \\
\text { cumaceans, brachiopods, sipunculans, } \\
\text { copepods }\end{array}$ & $\begin{array}{l}\text { Gocke et al. (1981) } \\
\text { De la Cruz \& Vargas (1987) } \\
\text { Fournier \& De la Cruz (1987) } \\
\text { Vargas (1987, 1988a, b, 1989a, b) } \\
\text { Watling \& Breedy (1988) } \\
\text { Emig \& Vargas (1990) } \\
\text { Cutler et al. (1992) } \\
\text { Mielke (1992) }\end{array}$ & $\begin{array}{l}1,11 \\
1 \\
1 \\
1 \\
1,13 \\
1,14 \\
1,15,16 \\
17\end{array}$ \\
\hline \multicolumn{3}{|c|}{$\begin{array}{l}\text { 1: Universidad de Costa Rica (CIMAR); 2: University of Delaware, Lewes (USA); 3: California } \\
\text { State University, Long Beach (USA); 5: Mount Ida College, Boston (USA); 11: Institut für } \\
\text { Meereskunde, Kiel (Germany); 13: University of Maine, Walpole (USA); 14: Station Marine } \\
\text { d'Endoume, Marseille (France); 15: Hamilton College, New York (USA); 16: Harvard University, } \\
\text { Cambridge (USA); 17: Zoologisches Institut und Museum der Universität Göttingen (Germany) }\end{array}$} \\
\hline
\end{tabular}

writing the proposal to publication of the results. This approach has also worked in cooperative efforts with more than a dozen research centres (Tables 1 and 2). As a result of these studies, the Gulf of Nicoya is considered unique in the sense that it is fertilized by a type of permanent upwelling, driven by the positive nature of the estuary and facilitated by the narrow shelf separating the mouth from the deep nutrient-rich waters of the Pacific (Fig.1). Large annual salinity variations take place in the Gulf, which are in direct response to the occurrence of a rainy season (May through November) and a dry season (December through April). During the rainy season the estuary has marked vertical and horizontal gradients, that are disrupted by winds and tidal mixing (mean tidal range $=2.3 \mathrm{~m}$ ) during the dry season (Epifanio et al., 1983; Voorhis et al., 1983). This marked seasonality of environmental factors is also reflected by some components of the biota, and an important number of papers published to date emphasize this aspect (Tables 1 and 2). More than 200 species of fish and nearly 400 species of benthic invertebrates have been identified, the ecology of most of them being relatively unknown. Joint research has also contributed to the study of mangroves (the most important coastal vegetation in the Gulf), and preliminary efforts have been made to study red tides and marine fungi (Table 1). Trace metal concentrations in sediment and invertebrates were evaluated recently and concentrations appear characteristic of nonindustrialized estuaries, except at the mouth of the Tarcoles river, where chromium is important (Dean et al., 1986; Fuller et al., 1990).

The study of benthic communities is an important component of the ecological 
evaluation programme of the Gulf of Nicoya, and work with foreign scientists has also played a leading role (Table 2). Benthic research has focused primarily on the description of structural aspects of communities (variation in space and time of the numbers of individuals and species). Future cooperative research will probably find an unexplored field in the study of community function (energy flow). Some findings from previous research cited in Table 2 are: a total of 56000 individuals belonging to 98 species was collected in trawl samples from 17 stations. Decapod crustaceans were the dominant taxon, with 54 species (Maurer et al., 1984). Grab samples, taken at 42 stations, yielded 4684 individuals and 205 species of macrofauna, of which polychaete worms were represented by 120 species, followed by crustaceans (46 spp.), and molluscs (22 spp.). Maximum density was 8744 individuals per square metre, and maximum diversity $\left(\mathrm{H}^{\prime}\right)$ was 3.09, which was not as high as expected for a tropical estuary (Maurer \& Vargas, 1984). Similar results were obtained by core sampling at an intertidal mud flat. Statistical methods, however, revealed a seasonal pattern of this mud flat community, with several species showing marked seasonal peaks of abundance (Vargas, 1987, 1988, 1989a, b.). A survey of the meiofauna conducted at this mud flat indicated that four groups, Nematoda, Foraminifera, Copepoda, and Ostracoda, accounted for $96 \%$ of the number of individuals. A density in excess of two million individuals per square metre ranks among the highest reported for tropical intertidal environments (De la Cruz \& Vargas, 1987; Vargas, 1988). Recent efforts have focused on taxonomic studies, particularly on groups such as cumaceans, copepods, brachiopods, and sipunculans (Table 2).

A survey of the literature on tropical benthic research indicates that reports based on data collected over a year or more are scarce (Alongi, 1989, 1990). Thus, little work exists relating seasonal environmental factors to fluctuations in abundance and diversity. Of great help in understanding the role of abiotic and biotic factors (predation, competition, reproductive strategies) is the comparative study of tropical and temperate communities. The number of papers addressing this topic is also relatively small, notable exceptions being those of Epifanio \& Dittel (1982), Warwick \& Ruswahyuni (1987), and Reise (1991).

Benthic scientists in temperate regions have accumulated many years of experience in the study of the role of the environmental and biological factors influencing the structure and function of soft-bottom communities (Reise, 1985). However, studies of this nature are rare in the tropics (Alongi, 1989, 1990). Thus, cooperative research is most welcome on topics such as reproductive strategies, larval transport and substratum selection, colonization of new and disturbed habitats, interactions between and among size groups (microfauna-meiofauna-macrofauna), and physiological tolerances toward salinity, temperature, and pollutants.

Caging experiments in different latitudes have produced, with a few exceptions, a significant increase in the number of individuals and species inside caged areas. This increase is most obvious in experiments conducted in temperate latitudes (Reise, 1977; Vargas, 1988). The usual explanation for these results is that the cage excludes predators, allowing some of the prey species to reach high abundances. Reise (1985) points out, however, that it is often impossible to separate the effects of predation from those of disturbance. Thus, the role of disturbance in community structure might be more important than predation on a community where most of the species are sediment re-workers (Vargas, 1988). In spite of these interpretation problems, caging experiments are simple and affordable tools to study community responses to external factors. Yet, the 
number of such experiments conducted in the tropics is negligible, the one conducted by the author being the only study published on a tropical intertidal mud flat (Vargas, 1988).

The experimental manipulation of communities has produced significant advances in the study of tropical rocky intertidal benthos (Ansell \& Morton, 1987; Alongi, 1989). As was mentioned before, considerable experience concerning this topic also exists in temperate latitudes (e.g. Reise, 1985) This experience facilitates comparisons and helps to avoid pitfalls in experimental design, and data analyses (cf. Burd et al., 1990). Cooperative studies on this branch of field ecology are also a priority subject of the ecological evaluation programme of the Gulf of Nicoya.

The ecological information that has been gathered since 1979, the existence of a marine research centre and an active group of local scientists, and the success of past cooperative research with foreign institutions, form a solid basis for any future effort in scientific cooperation.

Acknowledgements. This research was made possible by grants from the Universidad de Costa Rica (Projects 808-88-423, 808-90-410). Funds from the University of Costa Rica and the Biologische Anstalt Helgoland allowed the author to present this paper at the Symposium. This is CIMAR contribution No. 180.

\section{LITERATURE CITED}

Alongi, D., 1989. Ecology of soft-bottom benthos: a review with emphasis on emerging concepts. Revta Biol. trop. 37, 85-100.

Alongi, D., 1990. The ecology of tropical soft-bottom benthic ecosystems. - Oceanogr. mar. Biol. 28, $381-496$.

Ansell, A. D. \& Morton, B., 1987. Alternative predation tactics of a naticid gastropod. - J. exp. mar. Biol. Ecol. 111, 109-119.

Bartels, C., Price, K., López, M. \& Bussing, W., 1983. Occurrence, distribution, abundance and diversity of fishes in the Gulf of Nicoya, Costa Rica. - Revta Biol. trop. 31, 75-101.

Bartels, C., Price, K. S., López, M. \& Bussing, W., 1984. Ecological assessment of finfish as indicators of habitats in the Gulf of Nicoya, Costa Rica. - Hydrobiologia 112, 197-207.

Borjesson, D. L. \& Szelistowski, W. A., 1989. Shell selection, utilization, and predation in the hermit crab Clibanarius panamensis Stimpson in a tropical mangrove estuary. - J. exp. mar. Biol. Ecol. $133,213-228$.

Burd, B., Nemec, A. \& Brinkhurst, R. O., 1990. The development and application of analytical methods in benthic marine infaunal studies: - Adv. mar. Biol. 26, 169-247.

Campos, J., Burgos, B. \& Gamboa, C., 1984. Effect of shrimp trawling on the commercial ichthyofauna of the Gulf of Nicoya, Costa Rica. - Revta Biol. trop. 32, 203-207.

Campos, J. \& Gamboa, C., 1989. An artificial tire reef in a tropical marine system: a management tool. - Bull. mar. Sci. 44, 757-766.

Cruz, E. de la \& Vargas, J. A., 1987. Abundancia y distribución vertical de la meiofauna en la playa fangosa de Punta Morales, Golfo de Nicoya, Costa Rica. - Revta Biol. trop. 35, 363-367.

Cutler, N., Cutler, E. \& Vargas, J. A., 1992. Peanut worms (Phylum Sipuncula) from Costa Rica. Revta Biol. trop, 40, 153-158.

Dean, H. K., Maurer, D. Vargas, J. A. \& Tinsman, C. H. 1986. Trace metal concentrations in sediment and invertebrates from the Gulf of Nicoya, Costa Rica. - Mar. Pollut. Bull. 17, 128-131.

DeVries, M., Epifanio, C. E. \& Dittel, A. I., 1983a. Reproductive periodicity of the tropical crab Callinectes arcuatus Ordway in the Gulf of Nicoya, Costa Rica. - Estuar. coast. Shelf Sci. 17, $709-716$.

DeVries, M., Epifanio, C. E. \& Dittel, A. I., 1983b. Lunar rhythms in the egg hatching of the subtidal crustacean Callinectes arcuatus Ordway (Decapoda; Brachyura). - Estuar; coast. Shelf Sci. 17. $717-724$. 
Dittel, A. 1991. Distribution, abundance and sexual composition of stomatopod crustacea in the Gulf of Nicoya, Costa Rica. - J, crust. Biol. 11, 269-276.

Dittel, A., \& Epifanio, C. E., 1984. Growth and development of the portunid crab Callinectes arcuatus Ordway: zoeae, megalopae, and juveniles. - J. crust. Biol. 4, 491-494.

Dittel, A., Epifanio, C. E. \& Chavarría, J. B., 1985. Population biology of the portunid crab Callinectes arcuatus Ordway in the Gulf of Nicoya, Costa Rica; Central America. - Estuar. coast. Shelf Sci. 20, 593-602.

Dittel, A. I., Epifanio, C. E. \& Lizano, O., 1991. Flux of crab larvae in a mangrove creek in the Gulf of Nicoya, Costa Rica. - Estuar. coast. Shelf Sci. 32, 129-140.

Emig, C. \& Vargas, J. A., 1990. Glottidia audebarti Broderip (Brachiopoda, Lingulidae) from the Gulf of Nicoya, Costa Rica. - Revta Biol. trop. 38, 251-258.

Epifanio, C. E. \& Dittel, A., 1982. Comparison of dispersal of crab larvae in Delaware Bay, (USA) and the Gulf of Nicoya, Central America. In: Estuarine comparison. Ed. by V. Kennedy. Acad. Press, New York, $447-487$.

Epifanio, C. E. \& Dittel, A. I., 1984. Seasonal abundance of Brachyuran crab larvae in a tropical estuary: Gulf of Nicoya, Costa Rica, Central America. - Estuaries 7, 501 -505.

Epifanio, C. E., Maurer, D. \& Dittel, A. I., 1983. Seasonal changes in nutrients and dissolved oxygen in the Gulf of Nicoya, a tropical estuary on the Pacific coast of Central America. - Hydrobiologia 101, 231-238.

Fournier, M. L. \& Cruz, E. de la, 1987. Reproduction of the cockle Anadara grandis, in Costa Rica. Naga $10,6$.

Fuller, C. C., Davis, J. A., Cain, D. J., Lamothe, P. J., Fries, T. L., Fernández, G., Vargas, J. A. \& Murillo, M. M., 1990. Distribution and transport of sediment-bound metal contaminants in the Rio Grande de Tárcoles, Costa Rica (Central America). - Wat. Res. 24, 805-812.

Gocke, K., Vitola, M. \& Rojas, G., 1981. Oxygen consumption patterns in a mangrove swamp on the Pacific coast of Costa Rica. - Revta Biol. trop. 29, 143-154.

Gocke, K., Cortés, J. \& Villalobos, C., 1990. Effects of red tides on oxygen concentration and distribution in the Gulf of Nicoya, Costa Rica. - Revta Biol. trop. 38, 401-407.

Hatcher, B. H., Johannes, R. E. \& Robertson, A. I., 1989. Review of research relevant to the conservation of shallow marine ecosystems. - Oceanogr. mar. Biol. 27, 337-414.

Maurer, D. \& Vargas, J. A., 1984. Diversity of soft-bottom benthos in a tropical estuary: Gulf of Nicoya, Costa Rica. - Mar. Biol. 81, 97-106.

Maurer, D., Epifanio, C. E., Dean, H. K., Howe, S., Vargas, J. A., Dittel, A. I. \& Murillo, M., 1984. Benthic invertebrates of a tropical estuary: Gulf of Nicoya, Costa Rica. - J. nat. Hist. 18, $47-61$.

Maurer, D., Vargas, J. A. \& Dean, H. K., 1988. Polychaetous annelids from the Gulf of Nicoya, Costa Rica. - Int. Revue ges. Hydrobiol. 73, 43-59.

Mielke, W., 1992. Six representatives of the Tetragonicipitidae (Copepoda) from Costa Rica. Microfauna mar. 7, 101-146.

Murillo, L., 1990. La circulación de las mareas en el Golfo de Nicoya. - Tecnol. Marcha 10, 51-76.

Perry, D., 1988. Effects of associated fauna on growth and productivity in the red mangrove. Ecology 69, 1064-1075.

Ramírez, A. R., Szelistowski, W. A. \& López, M., 1989. Spawning pattern and larval recruitment in Gulf of Nicoya anchovies (Pisces: Engraulidae). - Revta Biol. trop. 37, 55-62.

Ramírez, A. R., López, M. I. \& Szelistowski, W. A., 1990. Composition and abundance of ichthyoplankton in a Gulf of Nicoya mangrove estuary. - Revta Biol. trop. 38, 463-466.

Reise, K., 1977. Predator exclusion experiments in an intertidal mud flat. - Helgoländer wiss. Meeresunters. 30, 263-271.

Reise, K., 1985. Tidal flat ecology. Springer, Berlin, $191 \mathrm{pp}$.

Reise, K., 1991. Macrofauna in mud and sand of tropical and temperate tidal flats. In: Estuaries and coasts: spatial and temporal intercomparisons. Ed. by M. Elliott \& J. P. Ducrotoy. Olsen \& Olsen, Fredensborg, 211-216.

Soto, R., 1988. Geometry, biomass allocation and leaf demography of Avicennia germinans (L.) L. Avicenniaceae) along a salinity gradient in Salinas, Puntarenas, Costa Rica. - Revta Biol. trop. 36, 309-323.

Szelistowski, W. A. \& Garita, J., 1989. Mass mortality of sciaenid fishes in the Gulf of Nicoya, Costa Rica. - Fish. Bull. U.S. 87, 363-365. 
Thorne, R. E., Hedgpeth, J. B. \& Campos, J., 1989. Hydroacoustic observations of fish abundance and behaviour around an artificial reef in Costa Rica. - Bull. mar. Sci. 44, 1058-1064.

Ulken, A., Víquez, R., Valiente, C. \& Campos, M., 1990. Marine fungi (Chytridiomycetes and Thraustochytriales) from a mangrove area at Punta Morales, Gulf of Nicoya, Costa Rica, Central America, - Revta Biol. trop. 38, 243-250.

Vargas, J. A., 1987. The benthic community of an intertidal mud flat in the Gulf of Nicoya, Costa Rica. Description of the community. - Revta Biol. trop. 35, 229-316.

Vargas, J. A., 1988a. Community structure of macrobenthos and the results of macropredator exclusion on a tropical mud flat. - Revta Biol. trop. 36, 287-308.

Vargas, J. A., 1988b. A survey of the meiofauna of an eastern tropical Pacific intertidal mud flat. Revta Biol. trop. 36, 541-544.

Vargas, J. A., 1989a. A three year survey of the macrofauna of an intertidal mud flat in the Gulf of Nicoya, Costa Rica. In: Proceedings of the 6th Symposium on Coastal and Ocean Management. Ed. by O. Magoon, M. Converse, D. Miner, L. T. Tobin \& D. Clark. American Society of Civil Engineers, New York, 2, 1905-1919.

Vargas, J. A., 1989b. Seasonal abundance of Coricuma nicoyensis Watling \& Breedy (Crustacea, Cumacea) on an intertidal mud flat in the Gulf of Nicoya, Costa Rica. - Revta Biol. trop. 37, 207-211.

Vargas, J. A., Dean, H. K., Maurer, D. \& Orellana, P., 1985. Lista preliminar de invertebrados asociados a los sedimentos del Golfo de Nicoya, Costa Rica. - Brenesia 24, 327-342.

Voorhis, A., Epifanio, C. E., Maurer, D., Dittel, A. I. \& Vargas, J. A., 1983. The estuarine character of the Gulf of Nicoya and embayment on the Pacific coast of Central America. - Hydrobiologia 99, 225-237.

Warwick, R. M. \& Ruswahyuni, 1987. Comparative study of the structure of some tropical and temperate marine soft-bottom macrobenthic communities. - Mar. Biol. 95, 641-649.

Watling, L. \& Breedy, O., 1988. A new cumacean (Crustacea) genus from beaches of Golfo de Nicoya, Costa Rica. - Revta Biol. trop. 36, 527-533.

Wehrtmann, I., 1990. Distribution and reproduction of Ambidexter panamense and Palaemonetes schmitti in Pacific Costa Rica. (Crustacea, Decapoda). - Revta Biol. trop. 38, 327-329.

Wehrtmann, I. \& Dittel, A. I., 1990. Utilization of floating mangrove leaves as a transport mechanism of estuarine organisms, with emphasis on Decapod Crustacea. - Mar. Ecol. Prog. Ser. 60, 67-73. 